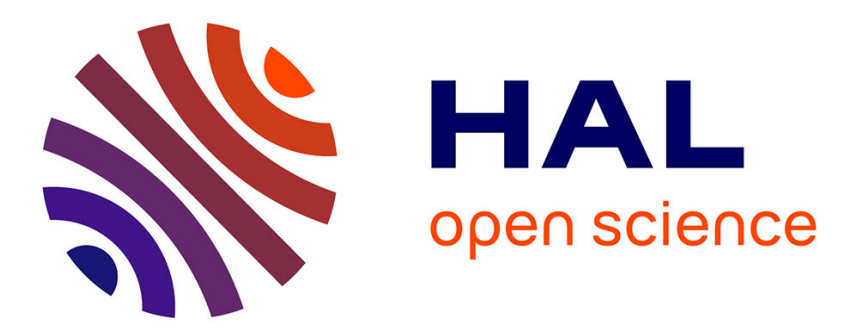

\title{
DETECTION AND LOCALIZATION OF SOUNDS BY HUMAN IN FREE FIELD CONDITION
}

\author{
M. Tarasova
}

\section{To cite this version:}

M. Tarasova. DETECTION AND LOCALIZATION OF SOUNDS BY HUMAN IN FREE FIELD CONDITION. Journal de Physique IV Proceedings, 1992, 02 (C1), pp.C1-229-C1-232. 10.1051/jp4:1992147 . jpa-00251218

\section{HAL Id: jpa-00251218 https://hal.science/jpa-00251218}

Submitted on 1 Jan 1992

HAL is a multi-disciplinary open access archive for the deposit and dissemination of scientific research documents, whether they are published or not. The documents may come from teaching and research institutions in France or abroad, or from public or private research centers.
L'archive ouverte pluridisciplinaire HAL, est destinée au dépôt et à la diffusion de documents scientifiques de niveau recherche, publiés ou non, émanant des établissements d'enseignement et de recherche français ou étrangers, des laboratoires publics ou privés. 


\title{
DETECTION AND LOCALIZATION OF SOUNDS BY HUMAN IN FREE FIELD CONDITION
}

\author{
M.V. TARASOVA \\ N.N. Andreyev Acoustical Institute, Academy of Sciences of the USSR, 117036 Moscow, Shvernik \\ St. 4, USSR
}

RESUME - On décrit les experiences psychoacoustiques concemant la localisation et la détection simultanees des tons 0,5 $\mathrm{kHz}$ et $4,0 \mathrm{kHz}$ pres du seull de détection. On montre que dans ces conditions (1) la localisation est beaucoup moins effective que la détection et (2) les tons basse-fréquence sont localisés avec moins de préision que ceux haute-Iréquence.

ABSTRACT - Psychoacoustical experiments on simultaneous detection and Iocalization of $0,5 \mathrm{kHz}$ and $4.0 \mathrm{kHz}$ tones at near-threshold levels are reported. It is shown that (1) localization Is accomplished much less effectively than detection and (2) near detection threshold. Iow-frequency tones are looallzed with less accuracy than high-frequency tones.

In natural condltions the tasks of sound detection and local1zation are closely related; in psychoacoustic experiments, however, they are treated separately. This paper aims to investigete a probIem of simultaneous detection and localization of sounds at levels close to detection threshold.

Experiments were carried out with six subjects aged 22-30 with no hearing loss. A subject was sltting on a seat placed on a metalIlo net in the centre of an anechole chamber $12 \times 12 \times 9 \mathrm{~m}^{3}$ large. On the helght of his ears seven identical loudspeakers were fixed unlformig on a semi-circumference $\pm \pi / 2,3 \mathrm{~m}$ in radius, so that the angle between adjacent loudspeakers was $\pi / 6$. The acoustio pressure at the placement of the head proved to be essentially the same for the loudspeakers fed by a reference electrlo signal. The experimenter and all the control circults were looated beyond the chamber; the subject and the experimenter communicated via a phone.

The listener, with his head immobile, had a task of detecting a signal from a loudspeaker and estimating its bearing. The $0.5 \mathrm{kHz}$ and $0,4 \mathrm{kHz}$ tonal pulses were used as stimuli.

At the first stage of the experiment detection thresholds for tonal pulses arriving from each of the seven loudspeakers were determined for all subjects. The pulse duration was $200 \mathrm{~ms}$, the raise and fall times were $20 \mathrm{~ms}$. A two-altemative forced-cholce procedure was used at this stage: the signal appeared at random either in the first or in the second observation interval, both marked by light flashes. After each wrong answer the signal Ievel was raised by $2 \mathrm{~dB}$; after two correot answers in succession 1 t was lowered by $2 \mathrm{~dB}$. The 
threshold was calculated by averaging the slgial level over 15 inversions (the first three inversions were Ignored). The threshold value determined by this procedure corresponds to the correct detection probability (CDP) value of $70.7 \%$ [1].

In the course of the main test session the signals arrived at random from different loudspeakers and the subject's task was to Indicate both the presentation interval and the loudspeaker number. Hence, a two-altemative (for detection) combined with a seven-aitermative (for localization) forced-cholce procedure with no feedback was used. In each run, 200 trials having the same sound level were presented to a subject. For every mun CDP and correct localization probability (CIP) were calculated. In order to provide a correct comparison between the results for two-alternative and seven-altemative procedure, sensitivity indexes $d^{\prime}$ [2] were calculated for detection and localization.

The results obtained show that all subjects had relatively high auditory sensitivity: the mean values of absolute thresholds for frequencies 0,5 and $4,0 \mathrm{kHz}$ were as $I 0 w$ as $-2,3 \mathrm{~dB} S P L$ and $-7,5 \mathrm{~dB}$ SPL respectively.

Such high sensitivity compared to that obtained with dichotic presentation of stimuli may be due to magnification effects In the outer ear. (Similar results were reported for sound detection by cat [3]). This effect manifests Itself particularly at $4.0 \mathrm{kHz}$ because at $0,5 \mathrm{kHz}$ the influence of pinna and the shielding effeot of the head are negligible.

The localization proved to be accomplished by the listeners much less effectively than the detection in the entire range of sound levels explored. In 11g.1 CDP (solid Iine) and CIP ( dashed Iine) values averaged over seven loudspeakers are shown as functions of sound level. It is evident that for all listeners a range of sound pressure exists in which detection is rather good while localization is highly erroneous. Furthermore, the CLP vs sound level curve grows much steeper for $0.5 \mathrm{kHz}$ than for $4.0 \mathrm{kHz}$ tones. Hence, in the near-threshold range low-frequency tones are locallzed considerably better than high-frequency ones. The same conclusion may be drawn from the analysis of $\mathrm{fig} .2$ where corresponding d values are plotted. We relate this effect to the fundamental diffexence in physlological mechanisms of sound localization in high-frequency and low-frequency reglons. It is well known that the main criterion for locallzation of low-frequency tones by the auditory system is the interaural delay of carrier cycles. The latter is coded by the delay of neural spikes in the left and right flbers of the auditory nerve. The accuracy of temporal coding is known to remain fairly high even at the lowest signal level. Moreover, at optimal frequency, the excltation phase is verg little level-dependent [4]. Thls allows to susgest that the Interaural delay analysis can remain quite effective down to threshold stimulus levels.

At $4,0 \mathrm{kHz}$ the carrier temporal pattern is hardly followed by the nerve fibers, and the main localization criterion becomes the interaural level rather than time difference. In the low-signal range the difference IImen for tones is known to be very high and diminlshes only gradually with increasing sound level. So, in this level range, the temporal localization mechanism acting at low frequencles seems to be more reliable than the amplitude one used for high-frequency tones.

The results mentioned above were obtained by data averaging over all loudspeakers. However, in near-threshold conditions, the 

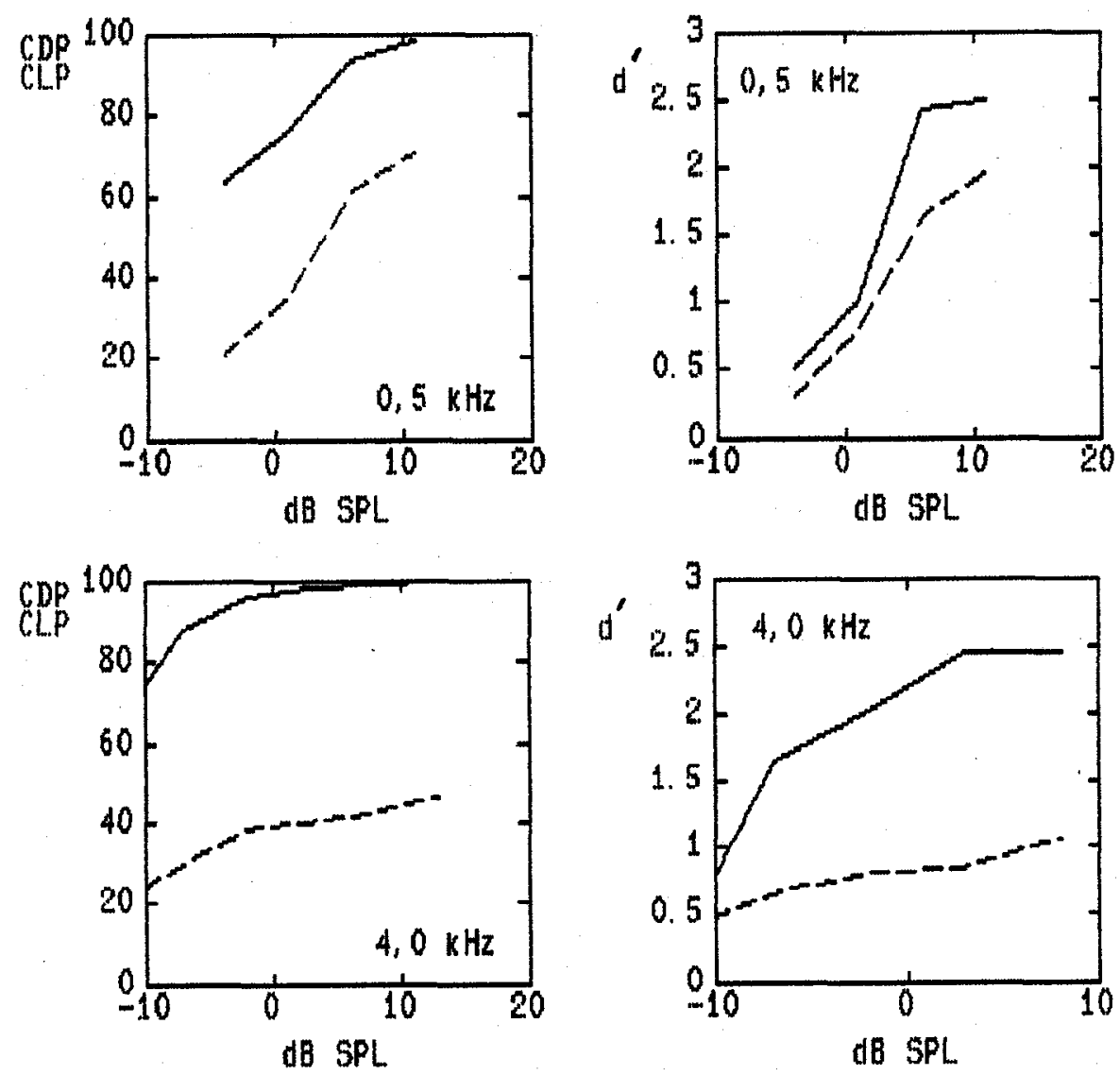

Fig. 1

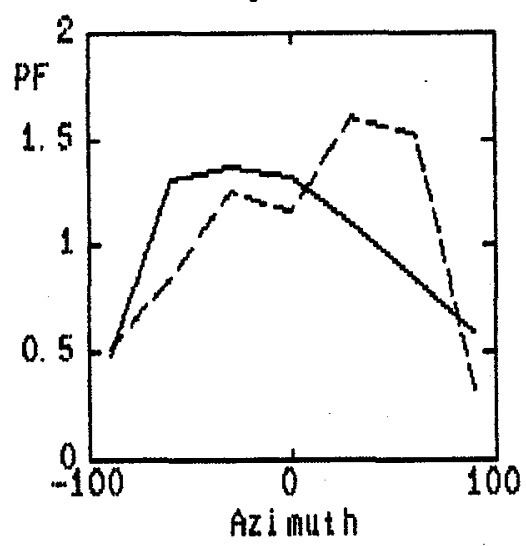

Fig. 2

$\mathrm{Fig} 3$ 
analysis of the auditory perception peculiarities related to the spatial location of sound sources is of considerable interest. So, for each loudspeaker a 'preference factor' ( PF) was evaluated. numericalis equal to the ratio of overall trials number a particular loudspeaker was pointed out by a subject ( no matter whether correctly or wrongly, to the actual number of signal presentations through this loudspeaker. PF values averaged over all subjects are presented on fig. 3 as function of source azimuth for $0,5 \mathrm{kHz}$ (the solid line) and $4,0 \mathrm{kHz}$ (the dashed line) tones. For each subject. the data used correspond to the signal level $2 \mathrm{~dB}$ higher than the subject's Individuel detection threshold. The curves of 1 Ig.3 suggest that for low-frequency signals the preferred directions correspond to the left-hand slde and for high-frequency ones - to the right-hand side position of the sound source. A pronounced edge effect is also evident - a drastio fall of PF values towards marginal loudspeakers located at $\pm \pi / 2$ with respect to saggital plane.These effects proved to be quite stable and well noticeable even at the highest levels of the slgmals used.

Finalis, the effect of flash light location on localization efflclency was noticed: the subject's attention was drawn to a definite azimuth by a fiash of light which source was attached to the corresponding loudspeaker ( the head did not move). As a result, some rise of CDP and CIP values for directions of Visual tuning was revealed, particularly at $4.0 \mathrm{kHz}$. Similar effect was recorded earlier by the author and investigated in detall for broadband signals with bandwidth $(0,1-12.0) \mathrm{kHz}$ using different methods of Ilstener's concentration $[5,6]$. Additional experiments showed that for slgnal having narrower bandwidth $(0,1-5,0) \mathrm{kHz}$, the effect persist but the influence of the subject's tuning is reduced.

\section{REFERENCES}

11/ Levitt,H.J., J.Acoust. Soc.Amer., 49, N2 (2), (1971), 467-477.

/2/ Thzeng,N.V. .Moscow, "Nauka". (1984),189-192 (In Russian).

/3/ Moore,D.R. , Semple,M.N. , Addison, P.D., Aitkin, I.M., Hearing Research, $13,(1984), 159-174$.

/4/ Anderson, D. ,Rose, J.E. , Hind, J.E. , Brugge, J.F., J. Acoust. Soo. Amer. , 49. (1971), 1131-1139.

15/ Tarasova,M.V., Dubrovsk1y, N.A., Colloque de phys1que, Ce, suppl.au N2, Tome $51,(1990), 175-178$.

16/ Tarasova,M.V. Dubrovskiy, N.A. In "Neurocomputers and attention I: neurobiology, synchronisation and chaos". "Manchester University Press", (1991),107-117. 